\title{
Ultrasonographic Monitoring of Gallbladder Dynamics during Fasting and Feeding Conditions in Sheep
}

\author{
K. W. ROMAŃSKI
}

Department of Animal Physiology, Faculty of Veterinary Medicine, Wrocław Agricultural University, Wrocław, Poland

Received July 16, 2003

Accepted February 11, 2004

Abstract

Romański K. W.: Ultrasonographic Monitoring of Gallbladder Dynamics during Fasting and Feeding Conditions in Sheep. Acta Vet. Brno 2004, 73: 29-35.

The aim of this study was to evaluate the use of real-time ultrasonography for long-term studies of ovine gallbladder motor function and the assessment of the dynamics of gallbladder contractility in various fasting conditions and as the consequence of feeding with hay and grain mixture. Five adult sheep were selected in order to find the gallbladder shape suitable for the application of the ellipsoid method to estimate the gallbladder volume. In these animals, the ultrasonographic maximal-size gallbladder images were obtained every $10 \mathrm{~min}$ for periods of 3-5 h. Seven series of gallbladder length and height measurements were performed on each animal and the results were used to estimate the gallbladder volume utilizing the ellipsoid method. In animals fasted for 2 days, the gallbladder volume changed significantly (from $12.4 \pm 1.2$ to $24.2 \pm 2.1 \mathrm{ml}$ ) in the fashion of cycles lasting usually longer than $100 \mathrm{~min}$. In 1-day fasted animals, the fluctuations of gallbladder volume were less clear than in 2-day fasted animals and ranged from $16.3 \pm 2.2$ to $26.8 \pm 4.3 \mathrm{ml}$. Feeding significantly lowered the gallbladder volume which gradually returned to values similar to those during the pre-feeding period. In non-fasted animals, feeding with hay evoked a longer contractile effect (control $30.6 \pm 2.9 \mathrm{ml}$, feeding $14.2 \pm 1.1 \mathrm{ml}, p<0.001$ ) than feeding with a grain mixture (control $31.0 \pm 3.3 \mathrm{ml}$, feeding $15.9 \pm 3.2 \mathrm{ml}, p<0.05$ ). Thus, the ultrasonographic method for gallbladder motility examination is useful in sheep and may provide important basic and clinical information. Furthermore, the results indicate that pre-duodenal mechanoreceptors and/or chemoreceptors can play a role in the control of gallbladder motility in sheep.

Sheep, gallbladder, volume estimation, hay, grain mixture

Ultrasonography (the real-time ultrasonography), as a non-invasive method has been used for many years in human and veterinary medicine to explore various functions of the organism (B on a gura and Fuentes 2000). Ultrasonography is particularly well applicable in the functional studies of fluid-filled organs including the digestive system (Mittal and Liu 2002). The gallbladder is one of the most suitable organs for this purpose. In veterinary medicine, the ultrasonography focuses mainly on the structural examination of gallbladder in dog and cat (Center 1996). The number of reports concerning the ultrasonographical assessment of the gallbladder function in animals has been gradually increasing (Romański and Siembieda 2002; Rothuizen et al. 1990). The diagnostic ultrasonographic examinations of the liver and gallbladder concern also the ruminant species (Braun and Hausammann 1992; Braun et al. 1995) but they are not a source of any information regarding the gallbladder function useful for clinicians.

Such information can be helpful for evaluation of clinical status when the gallbladder wall is altered and it is possible that the gallbladder motor function can be impaired resulting in bile flow disturbances. The first report about the kinetics of gallbladder function in ruminants included the gallbladder ultrasonographic examination of lambs in vitro (Wedmann et al. 1991). Several years ago it was demonstrated that the realtime ultrasonography is useful in the gallbladder motility study in adult sheep and the

Address for correspondence:

Prof. K. W. Romański

Animal Physiology Dept.

Univ. of Agriculture, Norwida str. 31, 50-375 Wrocław, Poland
Phone: +48713205422

Fax: +48713281567

E-mail: romanski@ozi.ar.wroc.pl

http://www vfu.cz/acta-vet/actavet htm 
initial data regarding gallbladder contraction parameters were presented (Romański and Siembieda 1998). Thus, the aim of this study was to study gallbladder contractility in fasted and non-fasted sheep monitored with an ultrasonographic method. The intention initiating this study was to determine the dynamics of gallbladder contraction in fasted sheep and to point out the differences between the dynamics of gallbladder motility after various periods of fasting and feeding of animals with two different kinds of foods.

\section{Materials and Methods}

Five sheep of Polish Merino breed weighing 34-41 kg each (without fleece) were used. Only animals possessing oval, more regular gallbladder shape, were selected (Romański and Siembieda 2002). Animals were regularly fed a good quality hay and a grain mixture (CP mixture, Dolpasz, Wrocław). Drinking water was not limited. Animals were clinically healthy and during the initial ultrasonographic exploration of the abdominal cavity no alterations or parasites were found.

The gallbladder images were performed with the use of the ultrasonograph Echo Son ts. 1000 exd Spinel with the sectorial ultrasound Spinel 3.5 MHz. Before the experiments, the hair was removed from right lateral thoracic region, within 8-11 intercostal spaces covering the area of about $150 \mathrm{~cm}^{2}$. The skin surface and the probe were lubricated with the special gel before ultrasonographic imaging. The ultrasound was applied to the skin to obtain the maximum gallbladder sizes. The gallbladder position was compared before and after feeding.

On every animal seven series of basic experiments were performed. The maximum length and the maximum height of the gallbladder were measured in longitudinal scans during the following experimental series: group 1 animals fasted about 46 h, 27 subsequent gallbladder measurements every 10 minutes; group 2 - animals fasted about 20 h, 27 gallbladder measurements; group 3 - animals fed $0.5 \mathrm{~kg}$ of hay and then with $200 \mathrm{~g}$ of the grain mixture, $4 \mathrm{~h}$ before the onset of the experiment, not fed during the experiment, 21 gallbladder measurements; group 4 - animals fasted about $20 \mathrm{~h}$ and fed with hay $(0.5 \mathrm{~kg})$ during the experiment after five control measurements performed until the end of feeding procedure (the total number of gallbladder size measurements in this group was 24); group 5 - animals fasted about $20 \mathrm{~h}$ and fed the grain mixture (200 g) during the experiment after five control measurements performed until the end of feeding procedure (the total number of measurements in this group was 24); group 6 - animals treated as in group 3 and fed $0.5 \mathrm{~kg}$ of hay during the experiments after three control measurements performed until the end of the experiment (the total number of the experiments in this group was 19); group 7 - animals treated as in group 3 and fed $200 \mathrm{~g}$ of the grain mixture during the experiment after three control measurements performed until the end of the experiment (the total number of the experiments in this group was 19). The time sequence of the experiments in groups $1-7$ performed in the same animal was random, however, at least one week was allowed after the experiment with longest fasting (group 1), at least two days were allowed after the experiments with one-day fasting performed without feeding (group 2) and at least one day was allowed between other experiments.

Furthermore, in order to verify the data, the longitudinal and transverse gallbladder imaging in two sheep was performed before and after feeding using of Hitachi EUB 405 ultrasonograph (Tokyo) with the probe of convex 5 $\mathrm{MHz}$ type and gallbladder scans were printed using Videoprinter type P $40 \mathrm{U}$ (Mitsubishi, Tokyo).

For calculations the ellipsoid formula, described earlier (Braun 1982; Dodds et al. 1985), was applied and the gallbladder volume was estimated as follows: 1) in the current study the maximum gallbladder length (a) and the maximum height (b) were measured from the longitudinal image, 2) from previous unpublished results of ultrasonographic studies of gallbladder in sheep the gallbladder volumes were calculated with ellipsoid method, then the asymmetry (flatness) coefficient ( $s$ ) was calculated from maximum width ( $c_{1}$, in transverse section) and maximum height $\left(b_{1}\right.$, in transverse section) according to the formula: $\left.s=c_{1}: b_{1}, 3\right)$ for the final gallbladder volume calculation the gallbladder width (c) value was calculated from the formula: $\mathrm{c}=\mathrm{b} \cdot \mathrm{s}, 4)$ the final gallbladder volume $(\mathrm{V})$ was calculated from the formula: $\mathrm{V}=1 / 6 \pi \cdot \mathrm{a} \cdot \mathrm{b} \cdot \mathrm{c}$, where $1 / 6 \pi$ was equal to 0.5233 .

The results were statistically evaluated and the mean value and the standard error of mean were calculated. The statistical significance was calculated (S awicki 1982). Firstly, ANOVA I test was performed for the whole data population and the rejection of null hypothesis was obtained. Then, ANOVA I (for different numbers of measurements) and ANOVA II (for the same number of measurements) tests were performed for separated populations (the data from 3-4 groups in the considered population) and similar results were obtained. Thus, the paired Student $t$-test was performed individually in each group.

\section{Results}

The representative images of ovine gallbladder after feeding are presented in Fig. 1 (Plate IV). The gallbladder shape visible in the Fig. 1 enables for application of ellipsoid formula for gallbladder volume estimation. 

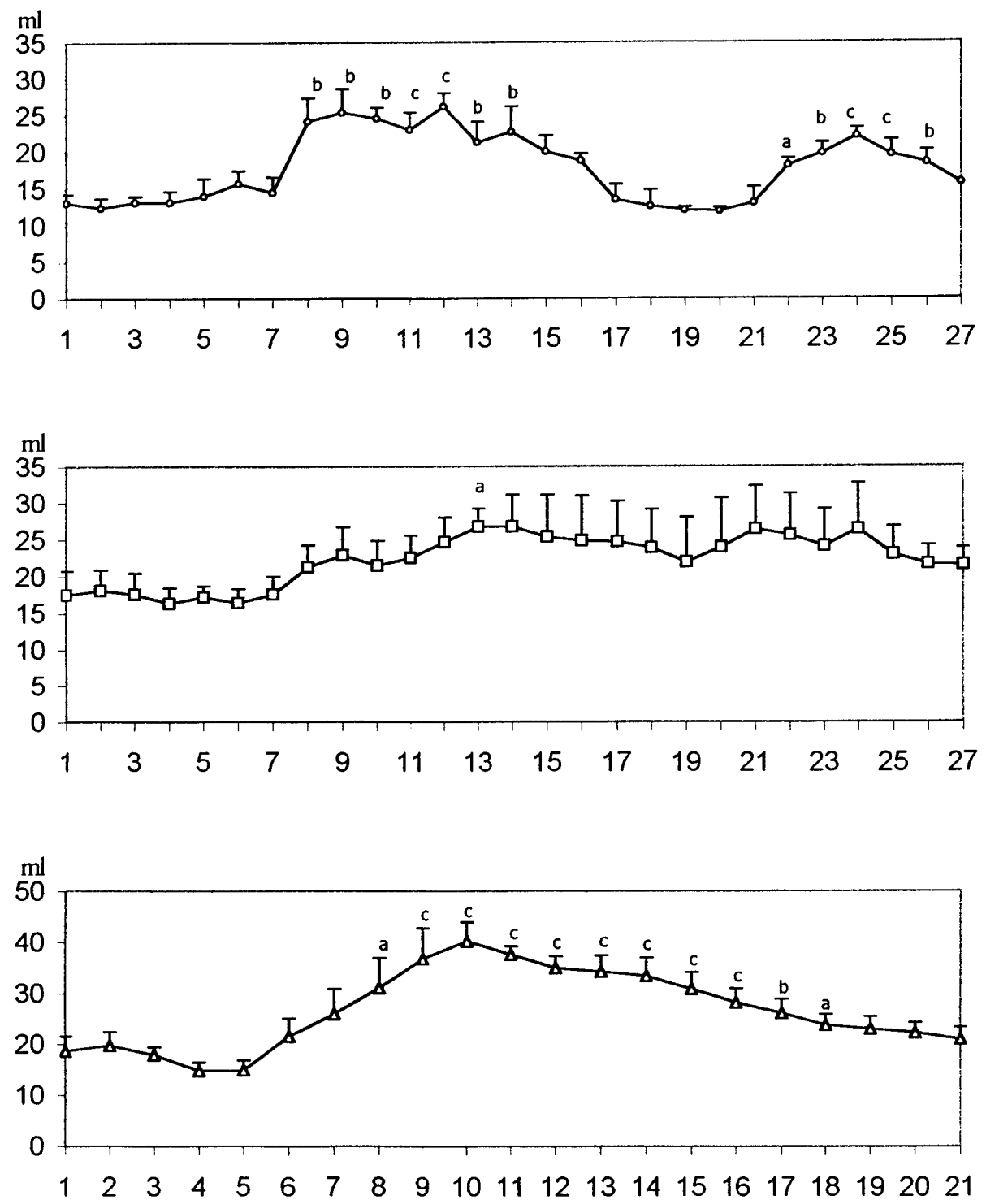

Fig. 2. The gallbladder dynamics of 2-day fasted sheep (group 1, upper panel), 1-day fasted sheep (group 2, middle panel) and in sheep fed $4 \mathrm{~h}$ before the experiment (group 3, lower panel). Gallbladder volume estimations were performed every 10 minutes.

Statistical significance: ${ }^{\mathrm{a}} p<0.05 ;{ }^{\mathrm{b}} p<0.01 ;{ }^{\mathrm{c}} p<0.001$ vs. the lowest values No. 2 for first series of statistical significance, first peak and No. 20 for second series of statistical significance, second peak (upper panel) or vs. values No. 4 (middle and lower panels). No significant differences of first five measurements among the groups were observed. Other detailed explanations as in the chapter Material and Methods.

The asymmetry coefficient was calculated for maximum, moderate and minimum gallbladder volumes previously calculated by means of the ellipsoid method. For the maximum gallbladder volumes (values above $80 \%$ of the largest gallbladder volume of the given non-fasted animal) asymmetry coefficient was equal to $1.0186(n=20)$. For moderate 

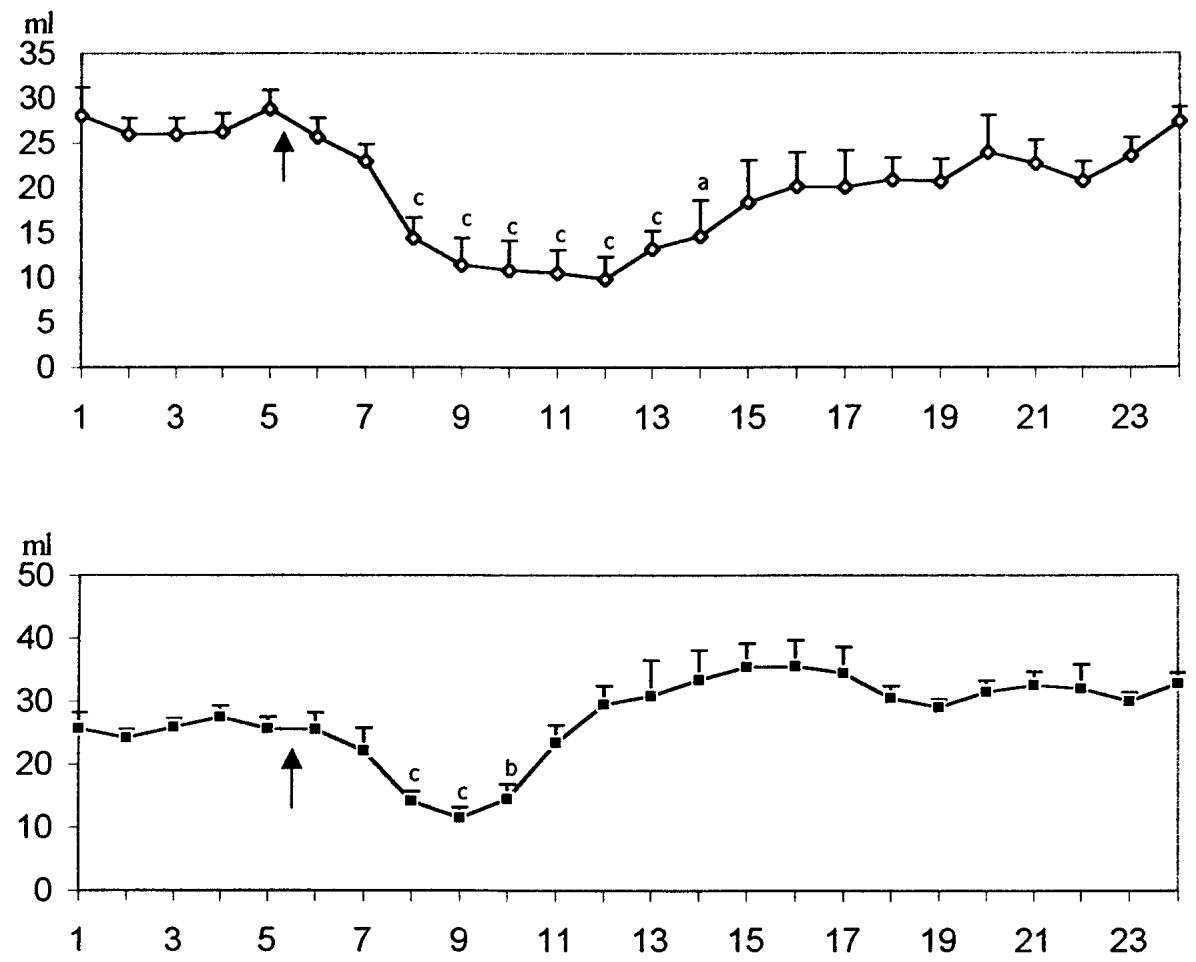

Fig. 3. The gallbladder dynamics in 1-day fasted sheep and fed (arrows) during the experiment with hay (group 4, upper panel) or with the grain mixture (group 5, lower panel). Statistical significance vs. the value just before termination of feeding (value No. 5). No statistical differences between control measurements in both groups was observed. Other explanations as in the legend to Fig. 2.

gallbladder volumes (values above 60 up to $80 \%$ of the largest gallbladder volume of the given non-fasted animal) the asymmetry coefficient was equal to $1.020(n=20)$. For the minimal gallbladder volumes (values until $60 \%$ of the largest gallbladder volume of the given non-fasted animal) the asymmetry coefficient was equal to $1.02136(n=26)$.

The fluctuations of gallbladder volumes in sheep fasted two days were more distinct than in animals fasted one day. In the latter group of animals it was hard to detect any statistical significance (Fig. 2). The fluctuations of the gallbladder volume were prolonged in animals fed few hours before the experiment.

Feeding hay to previously fasted animals evoked more rapid gallbladder contractile response than analogous feeding of animals that were not fasted (Fig. 3). In fasted animals, feeding the grain mixture also triggered the contractile response sooner than in non-fasted sheep. Additionally, this response was of longer duration (Fig. 4). When feeding hay and feeding grain mixture were compared, the effect of food concentrate was shorter. Rumination was observed mostly in group 3, in other groups rumination was observed incidentally.

\section{Discussion}

The results of our study indicate that the long-term gallbladder volume monitoring, using the ultrasonographic method, is applicable in sheep as in other non-ruminant animal species, i.e. in humans (Goerg and Spilker 2003) and dog (Rothuizen et al. 1990) as well as in 

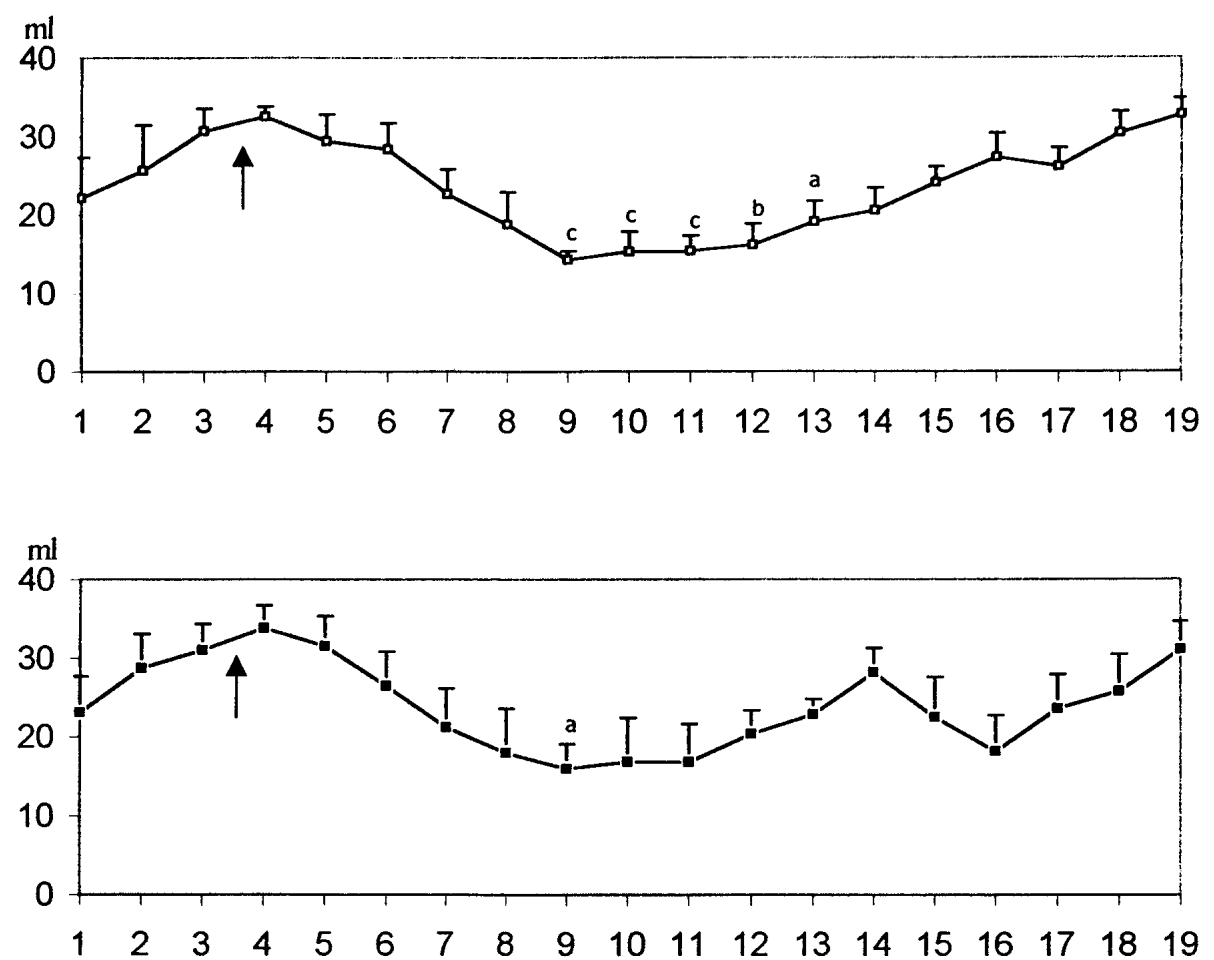

Fig. 4. The gallbladder dynamics in sheep fed $4 \mathrm{~h}$ before the experiment and then fed again (arrows) with $0.5 \mathrm{~kg}$ of hay (group 6, upper panel) or with the grain mixture (group 7, lower panel) during the experiment. Statistical significance calculated vs. the value No. 3. Other explanations as in the legend to Fig. 2 and Fig. 3.

other species in which this type of examination has been performed (Romański and Woźniak-Stolarska, 2002; Wedmann et al. 1991).

The asymmetry coefficient values used here were lower than previously calculated in dogs (Dąbrowski and Romański 1999) and the apparent reason for this difference was that in about $25 \%$ of measurements the gallbladder was laterally flattened what served as the partial equivalent of the top-bottom flattening observed more frequently in the dog. The relatively large rumen in sheep may change the direction of pressures in abdominal cavity of this animal species as compared with non-ruminant species. The increased pressure evoked by the rumen may affect the gallbladder shape since the gallbladder wall is relatively thin. This situation suggests that, unlike in the dog, the asymmetry coefficient can play a minor role in sheep.

The duration of fasting period affected directly proportionally the intensity of the gallbladder volume fluctuation in sheep. As it has already been demonstrated, in monogastric animals the gastrointestinal migrating motor complex (MMC) contributes to this fluctuation since the peak of inter-digestive gallbladder emptying coincides with the gastric phase 2 of MMC cycle and gallbladder relaxes mostly during phase 1 MMC (Kusano et al. 1990). In ruminants, MMC occurs during the inter-digestive period and is preserved also after feeding (Ruckebusch 1989). Thus, in the present study the MMC frequency lowered when either fasting period was shorter or perhaps the other causes induced more frequent fluctuation during this period. The changed state of the parasympathetic system might represent one of these reasons since its controlling role in the 
gallbladder motility has already been recognized (Bueno and Praddau de 1979). In fasted animals (group 1) and even in non-fasted sheep (group 3) relatively large oscillations were observed. Such spontaneous oscillations, especially in non-fasted animals cannot be explained solely by the occurrence of MMC persisting in ruminants after feeding. Thus, other influences, perhaps the enhanced postprandial refilling or rebound-like effects (Romański 2003) enganing neurohormonal mechanisms, could increase the fluctuations of gallbladder volume.

The gallbladder contracts after feeding, and this is the integral part of the complex response of the body to feeding (Granger et al. 1985). It is known that it concerns also sheep (Caple and Heath 1971). However, the effect of different kinds of food on gallbladder contraction in sheep has not been precisely studied so far. The results obtained in this study show that hay exerts a more pronounced gallbladder motor response than the grain mixture. It suggests the importance of the given type of mechanoreceptors in the regulation of ovine gallbladder emptying (Cottrell 1994) although a certain role of chemoreceptors cannot be excluded. The gastric mechanisms controlling the gallbladder function were already reported (Toouli and Al-Jiffry 2001; Ura et al. 1992) and these mechanisms, originating from the abomasum, might be responsible, at least in part, for the gallbladder dynamics observed in the present study.

The ovine model for gallbladder sonography can be useful in both experimental and clinical investigations. Sheep as relatively easily habituating animal, exhibiting similar gallbladder parameters and control mechanisms to man and dog appears to be the convenient species for this purposes. To obtain significant gallbladder contractions, few hours of fasting should be sufficient and for complete cycle of gallbladder kinetic study two-three gallbladder measurements before standard feeding (preferably with concentrate) and at least twelve postprandial gallbladder images can be recommended. Since the oscillations in gallbladder volume occur permanently it is always necessary to perform separate control experiments.

\section{Ultrasonografie dynamiky žlučníku v průběhu lačnění a sytosti u ovcí}

Cílem studie bylo vyhodnotit ultrasonografii $\mathrm{v}$ reálném čase pro dlouhodobé studie motorické funkce žlučníku ovcí a stanovení dynamiky kontraktility žlučníku za různých podmínek lačnění a jako důsledek krmení senem a koncentráty. U pěti dospělých ovcí byl nalezen tvar žlučníku vhodný k aplikaci elipsoidní metody pro odhad jeho obsahu. U těchto zviŕat bylo ultrasonografické zobrazení maximální velikosti žlučníku snímáno každých 10 min po dobu 3-5 hod. Na každém zvířeti bylo provedeno 7 sérií měření délek a šiřrek žlučníku a výsledky byly použity $\mathrm{k}$ určení obsahu žlučníku s využitím elipsoidní metody. U zvířat po 2 dnech lačnění se objem žlučníku signifikantně měnil (z $12.4 \pm 1.2$ na $24.2 \pm 2.1 \mathrm{ml}$ ), a to $\mathrm{v}$ cyklech zpravidla delších než $100 \mathrm{~min}$. V prvním dni lačnění byly změny objemu žlučníku méně zřetelné než 2 . den a pohybovaly se od $16.3 \pm 2.2$ do $26.8 \pm 4.3 \mathrm{ml}$. Krmení signifikantně zmenšilo objem žlučníku, jenž se postupně vrátil k hodnotám zjištěným před lačněním. Krmení senem vyvolalo delší kontrakci žlučníku (kontrola $30.6 \pm 2.9 \mathrm{ml}$, krmení $14.2 \pm 1.1 \mathrm{ml}, P<0.001$ ) než krmení jadrnou směsí (kontrola $31.0 \pm 3.3 \mathrm{ml}$, krmení $15.9 \pm 3.2 \mathrm{ml}, P<0.05$ ). Ultrasonografická metoda zjištování motility žlučníku je u ovcí efektivní a může poskytovat důležité základní a klinické informace. Mimoto výsledky ukazují, že preduodenální mechanoreceptory a/nebo chemoreceptory mohou hrát významnou roli v kontrole motility žlučníku u ovcí.

\section{References}

BONAGURA, JD, FUENTES, VL 2000: Echocardiography. In: ETTINGER, SJ, FELDMAN, EC: Textbook of Veterinary Internal Medicine. Diseases of the Dog and Cat. W. B. Saunders Co., Philadelphia, pp. 834-873 
BRAUN, B 1982: Untersuchung zur Abhängigkeit der Gallenblassenkontraktion und Wiederauffüllung vom weiblichen Zyklus. In: KRATOCHWIL, A., REINOLD, E. Ultraschalldiagnostik. Georg Thieme Verlag, Stuttgart, pp. 154-166

BRAUN, U, HAUSAMMANN, K 1992: Ultrasonographic examination of the liver in sheep. Am J Vet Res 53: 198-202

BRAUN, U, POSPISCHIL, A, PUSTERLA, N, WINDER, C 1995: Ultrasonographic findings in cows with cholestasis. Vet Rec 137: 537-543

BUENO, L, PRADDAUDE, F 1979: Electrical activity of the gallbladder and biliary tract in sheep and its relationships with antral and duodenal motility. Ann Biol Anim Bioch Biophys 19: 1109-1121

CAPLE, I, HEATH, T 1971: Function of the gall bladder in sheep. Q J Exp Physiol 56: 197-209

CENTER, SA 1996: Diseases of the gallbladder and biliary tree. In: GUILFORD, WG, CENTER, SA, STROMBECK, DR, WILLIAMS, DA, MEYER, DJ: Strombeck's Small Animal Gastroenterology. WB Saunders Co., Philadelphia, pp. 860-888

COTTRELL, DF 1994: Vagal reflex inhibition of motility in the abomasal body of sheep by antral and duodenal tension receptors. Vet Res Commun 18: 319-330

DĄBROWSKI, A, ROMAŃSKI, KW 1999: The novel method of estimation of gallbladder volume. Physiol Res 48: suppl. 1, S 113 (abstract)

DODDS, WJ, GROH, WJ, DARWEESH, RMA, LAWSON, TL, KISHK, SMA, KERN, MK 1985: Sonographic measurement of gallbladder volume. Am J Roentgenol 145: 1009-1011

GOERG, KJ, SPILKER, T 2003: Effect of peppermint oil and caraway oil on gastrointestinal motility in healthy volunteers: a pharmacodynamic study using simultaneous determination of gastric and gall-bladder emptying and orocecal transit time. Aliment Pharmacol Ther 17: 445-451

GRANGER, DN, BARROWMAN, JA, KVIETYS, PR 1985: Clinical Gastrointestinal Physiology. WB Saunders Co., Philadelphia, $347 \mathrm{p}$.

KUSANO, M, SEKIGUCHI, T, NISHIOKA, T, KAWAMURA, O, KIKUCHI, K, MATSUZAKI, T, HORIKOSHI, T, KOBAYASHI, S 1990: The relationship between interdigestive gallbladder and gastroduodenal motility in man. Gastroenterol Jpn 25: 568-574

MITTAL, RK, LIU, J 2002: Ultrasonography. In: SCHUSTER, MM, CROWELL, MD, KOCH, KL: Schuster Atlas of Gastrointestinal Motility in Health and Disease. BC Decker Inc., Hamilton, pp. 111-121

ROMAŃSKI, KW 2003: The rebound excitation triggered by anticholinergic drugs in ovine pyloric antrum, small bowel and gallbladder. J Physiol Pharmacol 54: 121-133

ROMAŃSKI, KW, SIEMBIEDA, J 1998: Ultrasonographic examination of gallbladder contractility in the sheep. Pol J Vet Sci 1: 27-30

ROMAŃSKI, KW, SIEMBIEDA, J 2002: Validation of the methods estimating gallbladder volume. Bull Vet Inst Pulawy 46: $95-104$

ROMANSSKI, KW, WOŹNIAK-STOLARSKA, B 2002: Interdigestive contractions of the gallbladder in rabbits: the real time ultrasonographical studies. Folia Med Cracov XLIII: 13-20

ROTHUIZEN, J, DE VRIES-CHALMERS HOYNCK VAN PAPENDRECHT, R, VAN DEN BROM, WE 1990: Postprandial and cholecystokinin-induced emptying of the gall bladder in dogs. Vet Rec 126: 505-507

RUCKEBUSCH, Y 1989: Gastrointestinal motor functions in ruminants. In: SCHULTZ, S G. Handbook of Physiology. The Gastrointestinal System. Am Physiol Soc, Bethesda, MD, pp. 1225-1282

SAWICKI, F 1982: Elementy statystyki dla lekarzy. PZWL, Warszawa, 228 p.

TOOULI, J, AL-JIFFRY, BO, 2001: Anatomy and physiology of the biliary tree and gallbladder. In: CLAVIEN, PA, BAILLIE, J, SUHOCKI, P: Diseases of the Gallbladder and Bile Ducts. Blackwell Science, Malden, MA, pp. 3-17

URA, K, SARNA, SK, CONDON, RE 1992: Antral control of gallbladder cyclic motor activity in the fasting state. Gastroenterology 102: 295-302

WEDMANN, B, SCHMIDT, G, WEGENER, M, COENEN, C, RICKEN, D, DRÖGE, C 1991: Sonographic evaluation of gallbladder kinetics: in vitro and in vivo comparison of different methods to assess gallbladder emptying. J Clin Ultrasound 19: 341-349 
Plate IV

Romański K. W.: Ultrasonographic... pp. 29-35
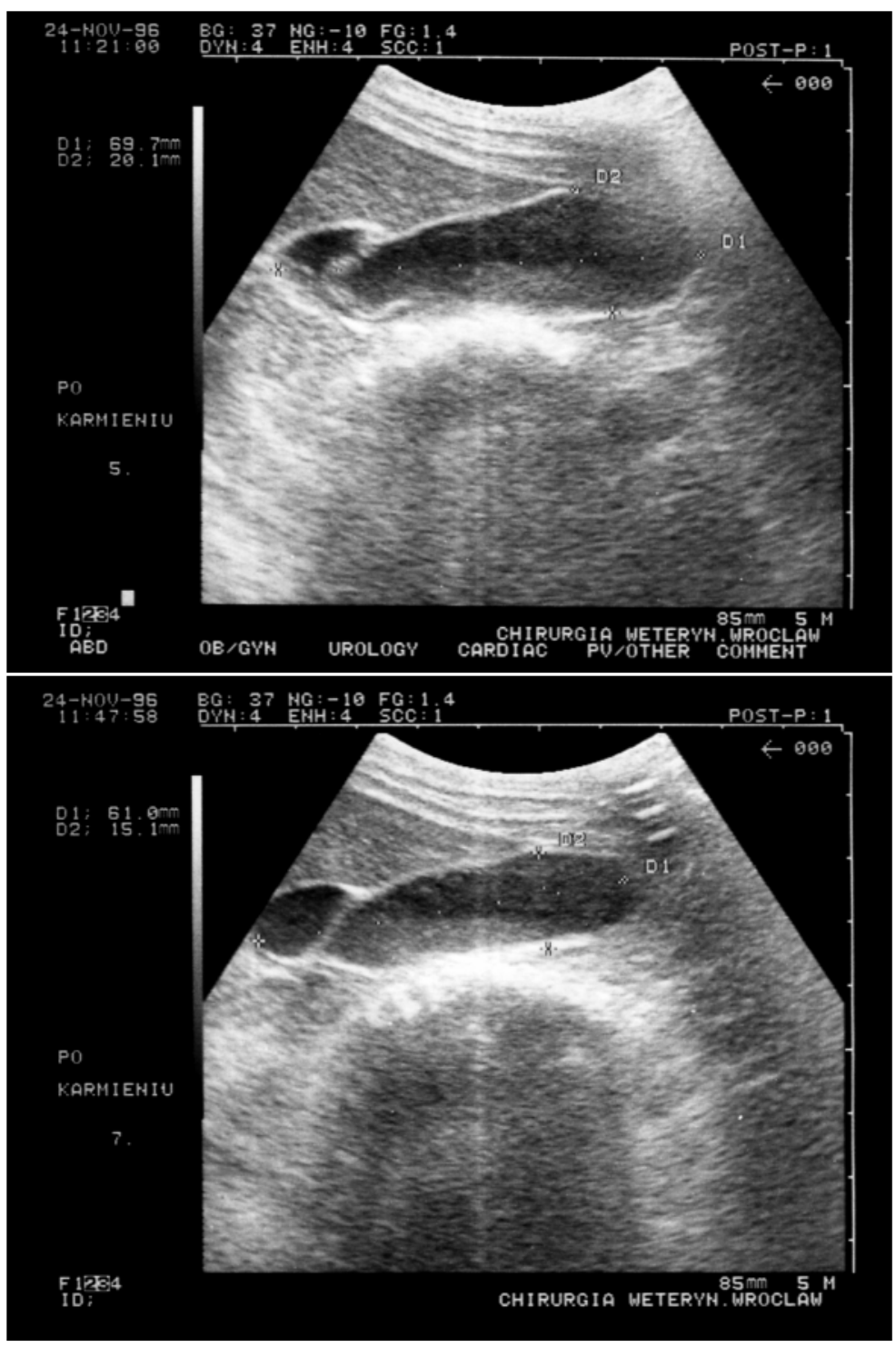

Fig. 1. The gallbladder longitudinal ultrasonograms of 1-day fasted sheep, performed 10 (top) and 20 (bottom) minutes after feeding with the $200 \mathrm{~g}$ of grain mixture. Note the gradual gallbladder emptying. Other detailed explanations as in the chapter Material and Methods. 